Civilizational Imperatives 
A VOLUME IN THE SERIES

\section{THE UNITED STATES IN THE WORLD}

founded by Mark Philip Bradley and Paul A. Kramer

edited by Benjamin Coates, Emily Conroy-Krutz, Paul A. Kramer, and Judy Tzu-Chun Wu

A list of titles in this series is available at cornellpress.cornell.edu. 


\section{Civilizational Imperatives}

Americans, Moros, and the Colonial World

Oliver Charbonneau 
Copyright (C) 2020 by Cornell University

All rights reserved. Except for brief quotations in a review, this book, or parts thereof, must not be reproduced in any form without permission in writing from the publisher. For information, address Cornell University Press, Sage House, 512 East State Street, Ithaca, New York 14850. Visit our website at cornellpress.cornell.edu.

First published 2020 by Cornell University Press

Printed in the United States of America

Library of Congress Cataloging-in-Publication Data

Names: Charbonneau, Oliver, 1984- author.

Title: Civilizational imperatives : Americans, Moros, and the colonial world / Oliver Charbonneau.

Description: Ithaca [New York] : Cornell University Press, 2020. | Series: The United States in the world | Includes bibliographical references and index.

Identifiers: LCCN 2020009191 (print) | LCCN 2020009192 (ebook) | ISBN 9781501750724 (hardcover) | ISBN 9781501750731 (pdf) | ISBN 9781501750748 (epub)

Subjects: LCSH: Muslims-Philippines-History-20th century. | Imperialism-History-20th century. | Philippines-ColonizationHistory-20th century. | United States-Foreign relationsPhilippines. | Philippines-Foreign relations-United States. Classification: LCC DS685 .C53 2020 (print) | LCC DS685 (ebook) | DDC 959.9/032-dc23

LC record available at https://lccn.loc.gov/2020009191

LC ebook record available at https://lccn.loc.gov/2020009192

Cover photograph: John Park Finley, governor of Zamboanga, attending the Convention of Moros at the Moro Exchange at Taluksangay, May 15-17, 1911. Burton Norvell Harrison Family Papers. Courtesy of the Library of Congress. 
For Victoria 
Just by saying that something was so, they believed that it was. I know now that these conquerors, like many others before them, and no doubt like others after, gave speeches not to voice the truth, but to create it.

Laila Lalami, The Moor's Account 